\title{
Antiprotozoal investigation of three Combretum species (Combretaceae) growing in Nigeria
}

\author{
OMONIKE O. OGBOLE ${ }^{1 *}$, TOLUWANIMI E. AKINLEYE ${ }^{1}$, PETER A. SEGUN² , PIUS S. \\ FASINU $^{3}$
}

\author{
${ }^{1}$ Department of Pharmacognosy \\ Faculty of Pharmacy \\ University of Ibadan \\ Ibadan, Nigeria \\ ${ }^{2}$ Department of Pharmacognosy \\ Faculty of Pharmacy \\ Olabisi Onabanjo University \\ Sagamu Campus, Nigeria \\ ${ }^{3}$ Department of Pharmaceutical Sciences \\ College of Pharmacy \& Health Sciences \\ Campbell University, Buies Creek \\ NC 27506, USA
}

*corresponding author: phone: +234 805643 4577, e-mail: nikeoa@yahoo.com

\section{Summary}

Introduction: Combretum species has been utilised for decades in African indigenous medical practices for the treatment of several parasitic infections.

Objectives: This study aims at investigating the antileishmanial, antiplasmodial and antitrypanosomal properties of Combretum racemosum, Combretum platypterum and Combretum zenkeri.

Methods: The leaf extracts of the plants were screened against two strains of Plasmodium falciparum using Plasmodium lactate dehydrogenase $(\mathrm{pLDH})$ assay; promastigote and amastigote forms of Leishmania donovani; and Trypanosoma brucei brucei using Alamar Blue assay. Cytotoxicity screening were also carried out on African green monkey kidney cell line (Vero) and human monocytic leukemia (THP-1) cell lines.

Results: C. racemosum was active against chloroquine-sensitive (D6) and chloroquine-resistant (W2) strains of $P$. falciparum ( $\mathrm{IC}_{50}$ of 25.6 and $26.7 \mu \mathrm{g} / \mathrm{ml}$, respectively) and exerted significant antiprotozoal activities against T. brucei brucei $\left(\mathrm{IC}_{50}=18.44 \mu \mathrm{g} / \mathrm{ml}\right)$. The extract of C. platypterum displayed a slightly lower 
antiplasmodial activity when compared to C. racemosum, while C. zenkeri was inactive against the parasites. In addition, the extracts failed to display significant inhibitory activity on the proliferation of L. donovani.

Conclusions: This study supports the ethnomedicinal use of C. racemosum. Further research needs to be carried out to identify the antiprotozoal compounds in C. racemosum, as this could be explored for possible antiprotozoal drug development.

Key words: Combretum racemosum, Combretum platypterum, Combretum zenkeri, antiprotozoal assay, infectious diseases

Słowa kluczowe: Combretum racemosum, Combretum platypterum, Combretum zenkeri, działanie przeciwpierwotniakowe, choroby zakaźne

\section{INTRODUCTION}

During the past decades, there has been an upsurge in the worldwide morbidity and mortality caused by infectious diseases, particularly in undeveloped countries. In fact, infectious diseases contribute to almost $40 \%$ of all deaths in these regions [1] and $20 \%$ of annual mortality in developed nations [2]. Leishmaniasis, Human African trypanosomiasis (HAT) and onchocerciasis transmitted by female sand fly, tsetse fly and black fly, respectively, have been included in the World Health Organization's list of seventeen neglected tropical diseases (NTDs) [3]. Despite the low public awareness associated with NTDs, especially in developed countries, NTDs affect residents of several low-income countries of Africa, Latin America and Asia, with over 1.4 billion people worldwide - including approximately 800 million children [4-6]. Due to the climatic condition that favours the existence of the protozoan vectors which transmit these diseases, the mortality, morbidity and socio-economic burden caused by these vector-borne protozoan diseases is higher in the tropical and subtropical regions when compared with the temperate zones, and also the poor hygienic conditions associated with low-income tropical countries [7].

Although significant milestones have been reached in microbiology, as exemplified in the discovery and application of several potent anti-infective agents for the treatment and control of these disease-causing organisms, the growing number of incidences of drug-resistant microorganisms and the emergence of new pathogenic organisms have continued to pose a threat to global public health. In addition, the genetic complexity of Plasmodium spp. which hindered the development of effective vaccine, antigenic variations in protozoan parasites that stimulate the evasion of host immune system as well as the toxicity of some currently used chemotherapeutic agents - all these are limitations in attempts of eradicating these protozoan diseases. These factors have stimulated the research in the discovery of new antimicrobial agents [8-10].

Plant-based medicine provides remedies against several ailments including infectious diseases. The population of most developing countries, especially those residing in rural settlements, utilise herbal medicine to meet their healthcare needs [11]. Medicinal plants have been reported to be useful in the management of protozoan infections and investigative work on these plants have led to the discovery of potent antiprotozoal agents such as quinine and artemisinin [12].

The Combretaceae family comprises of 20 genera, the largest of which is Combretum, with approximately 370 species. Combretum species are widely distributed in southern and western Africa, and widely used in Africa folk medicine for the treatment of several diseases such as constipation, diabetes, diarrhoea, digestive disorders, fever, haemorrhage, heart diseases, inflammation, jaundice, malaria, mental problems and toothache [13-15]. Although the antibacterial, antifungal, antiprotozoal and antiviral properties of several Combretum species from many African countries have been well investigated [15-19], the antiprotozoal activities of Combretum species indigenous to Nigeria have not been well studied. Therefore, this study was designed to address this gap by investigating the antiprotozoal activities of three Combretum species growing in Nigeria.

In this work, the methanol leaf extracts of Combretum platypterum (Welw.) Hutch. and Dalz., Combretum racemosum $\mathrm{P}$. Beauv and Combretum zenkeri 
Engl. \& Diels (Combretaceae family) were screened against chloroquine-resistant and chloroquine-sensitive strains of Plasmodium falciparum, Leishmania donovani (intracellular and extracellular forms) and Trypanosoma brucei brucei.

\section{MATERIAL AND METHODS}

\section{Plant collection and preparation of extracts}

The leaves of C. platypterum, C. racemosum and C. zenkeri were obtained from their natural habitat in the University of Ibadan (Nigeria). Plant identification and authentication was carried out at the Forest Herbarium Ibadan where Forestry Research Institute of Nigeria (FRIN), Ibadan, by Dr. Osiyemi who assigned the voucher specimen numbers for the plant materials as Forest Herbarium Ibadan (FHI) 109988, FHI 109989 and FHI 111997 for C. racemosum, C. platypterum and C. zenkeri, respectively. Voucher specimens were herbarium-mentioned in the preceding text. The plants were air-dried, pulverised, and extracted in methanol at a room temperature $\left(25-29^{\circ} \mathrm{C}\right)$ for $72 \mathrm{~h}$. The crude extracts obtained were concentrated in vacuo at $40^{\circ} \mathrm{C}$ and stored in a refrigerator at $4^{\circ} \mathrm{C}$ prior to use.

\section{Antiplasmodial assay}

The antiplasmodial potentials of the extracts were estimated using the Plasmodium lactate dehydrogenase $(\mathrm{pLDH})$ activity measurement, as earlier reported [20]. Erythrocytes infected with either chloroquine-sensitive (D6, Sierra Leone) or chloroquine-resistant W2 strains (Indochina) of Plasmodium falciparum (2\% parasitemia and 2\% hematocrit) were briefly prepared in Roswell Park Memorial Institute (RPMI) 1640 medium supplemented with $10 \%$ human serum and $60 \mu \mathrm{g} / \mathrm{ml}$ amikacin. The assay was carried out in a 96-well microplate which contained several concentrations ( $10 \mu \mathrm{l}$ each) of the extract and $200 \mu \mathrm{l}$ of the erythrocyte-infected preparation. Single concentration of $15.9 \mu \mathrm{g} / \mathrm{ml}$ of the extracts were tested for the primary antiplasmodial assay. Extracts that displayed more than $50 \%$ inhibition in the primary assay were subjected to secondary screening with treatment concentration ranging from 5.3 to $47.6 \mu \mathrm{g} / \mathrm{ml}$. Artemisinin and chloroquine (Sigma-Aldrich, St. Louis, USA) were used as the positive standards, while dimethylsulfoxide (DMSO)-containing medium served as negative control. The selectivity indices (SI) of the extracts were estimated by measuring their cytotoxicity on the African green monkey kidney cell line (Vero) following a method described in [21]. The SI was estimated by dividing the $\mathrm{IC}_{50}$ in Vero cells over the $\mathrm{IC}_{50}$ in $P$. falciparum. The experiment was carried out in triplicate and the $\mathrm{IC}_{50}$ values were statistically calculated from a dose-response curve obtained from the GraphPad'software.

\section{Antileishmanial assay}

The in vitro antileishmanial property of the extract was determined using Alamar Blue assay following an earlier described method [22]. The assay was performed on cell cultures of Leishmania donovani promastigotes and axenic amastigotes. The parasites were cultured in optimum growth conditions before commencement of treatment. The promastigotes were cultured in RPMI 1640 medium supplemented with $10 \%$ fetal bovine serum (FBS) and maintained at $\mathrm{pH} 7.4$ and $5 \% \mathrm{CO}_{2}$ at $26^{\circ} \mathrm{C}$, while the axenic amastigotes were cultured in RPMI 1640 medium supplemented with 4-morpholineethanesulfonic acid (MES) $(4.88 \mathrm{~g} / \mathrm{l}), \mathrm{L}$-glutamine $(298.2 \mathrm{mg} / \mathrm{l})$ and $10 \%$ FBS and maintained at $37^{\circ} \mathrm{C}$ and humidified atmosphere of $5 \% \mathrm{CO}_{2}$, with the medium $\mathrm{pH}$ fixed at 5.5. Single concentration $(20 \mu \mathrm{g} / \mathrm{ml})$ of the extract was used in the primary assay to treat the parasites with $72 \mathrm{~h}$ incubation period at $26^{\circ} \mathrm{C}$ and $37^{\circ} \mathrm{C}$, for promastigotes and axenic amastigotes, respectively. However, no secondary assay was carried out due to little or no activity displayed by the extract in the primary assay.

\section{Antitrypanosomal assay}

A method described recently [23] was modified and used for this test. Briefly, in obtaining 5000 parasites/ml, two-days-old culture of Trypanosoma brucei brucei was diluted in 96-well microplates, containing Iscove's Modified Dulbecco's medium (IMDM). The culture was at maintained $37^{\circ} \mathrm{C}$ in a humidified atmosphere of $5 \% \mathrm{CO}_{2}$. For the primary antitrypanosomal assay, $4 \mu \mathrm{l}$ of the extract, at a single concentration of $20 \mu \mathrm{g} / \mathrm{ml}$, was added into each well of the microplate containing $196 \mu \mathrm{l}$ of the IMDM-parasite culture to obtain a final volume of $200 \mu \mathrm{l}$. The incubation of the plates was carried out at $37^{\circ} \mathrm{C}$ in $5 \% \mathrm{CO}_{2}$ for $48 \mathrm{~h}$. Thereafter, $10 \mu \mathrm{l}$ of Alamar Blue was added into each 
well of the plates and incubated for $24 \mathrm{~h}$. At the expiration of the incubation period, the fluorescence could be measured in the microplate fluorometer FLUOstar Galaxy (BMG LabTechnologies $\mathrm{GmbH}$, Offenburg, Germany) at $544 \mathrm{~nm}$ excitation and $590 \mathrm{~nm}$ emission. The parasite culture was subjected to a secondary treatment using the method described above, except for the treatment concentration that ranged from 10 to $0.4 \mu \mathrm{g} / \mathrm{m}$. Pentamidine and amphotericin B were used as a positive standard. The $\mathrm{IC}_{50}$ values were determined from the dose-response analysis curve obtained from XLfit ver. 5.2.2.

\section{Cytotoxicity assay}

For the determination of the cytotoxicity of the extracts, four-day-old culture of transformed human monocytic cell line (THP-1) were cultured in RPMI 1640 medium to obtain a working cell concentration of $2.5 \times 10^{5}$ cells $/ \mathrm{ml}$. Phorbol 12-myristate 13-acetate (PMA; $25 \mathrm{ng} / \mathrm{ml}$ ) was added to the THP1 cell culture to transform the cells to adherent macrophages [24]. $200 \mu \mathrm{l}$ of cell suspension was added into each well of a 96 well plates and allowed to undergo overnight incubation at $37^{\circ} \mathrm{C}$ in $5 \% \mathrm{CO}_{2}$ humidified atmosphere. At the expiration of the incubation period, the old medium was replaced with a new one and the extracts were dispensed into the wells of the 96-well plates. Thereafter, the plates were incubated for $48 \mathrm{~h}$ at $37^{\circ} \mathrm{C}$ and $5 \% \mathrm{CO}_{2}$. Then, $10 \mu \mathrm{l}$ of Alamar Blue solution was incorporated into each well of the plates and incubated for $24 \mathrm{~h}$. Standard fluorescence was measured on a fluorometer at $544 \mathrm{~nm}$ excitation and $590 \mathrm{~nm}$ emission. The experiment was carried out in triplicate and the percentage inhibition of the extract was calculated using standard procedure.

Ethical approval: The conducted research is not related to either human or animal use.

\section{RESULTS}

\section{Antiplasmodial assay}

The methanol extract of C. platypterum and C. racemosum displayed $>50 \%$ growth inhibition $P$. falciparum strain D6 with values of $52 \%$ and $64 \%$, respectively (tab. 1) and therefore subjected to secondary antiplasmodial screening. In the secondary assay, the extracts displayed significant antiplasmodial activity against $P$. falciparum strains D6 and $\mathrm{W} 2$ with $\mathrm{IC}_{50}$ values lower than $50 \mu \mathrm{g} / \mathrm{ml}$. However, they displayed low SI with values ranging between 1.3 and 1.9 (tab. 1). C. zenkeri could not proceed beyond primary assay due to lack of significant inhibitory activity ( $<50 \%$ inhibition).

\section{Antileishmanial and antitrypanosomal assay}

In the primary antileishmanial assay, none of the three Combretum species had any significant inhibitory activity $(\geq 50 \%)$ on both the promastigote and axenic amastigote of $L$. donovani. Thus, there was no need for any further secondary assay. However, only C. racemosum (54\%) had a significant inhibitory activity against $T$. brucei brucei in the primary assay and was therefore subjected to secondary screening. C. racemosum showed good antitrypanosomal activity in the secondary assay with $\mathrm{IC}_{50}$ value of $18.44 \mu \mathrm{g} / \mathrm{ml}$ (tab. 2).

\section{Cytotoxicity assay}

All the three Combretum species exhibited less than $50 \%$ inhibition on the THP1 cells with the highest

Table 1.

In vitro antiplasmodial activity of the methanol extract of three Combretum species against $P$. falciparum strains

\begin{tabular}{|c|c|c|c|c|c|c|}
\hline \multirow[t]{2}{*}{ Plant extract } & \multirow{2}{*}{$\begin{array}{c}\begin{array}{c}\text { Primary assay } \\
{[\% \text { inhibition }]}\end{array} \\
\text { D6 }\end{array}$} & \multicolumn{3}{|c|}{$\begin{array}{l}\text { Secondary assay } \\
\mathrm{IC}_{50}[\mu \mathrm{g} / \mathrm{ml}]\end{array}$} & \multicolumn{2}{|c|}{ SI } \\
\hline & & D6 & $\mathrm{W} 2$ & Vero & D6 & W2 \\
\hline C. zenkeri & 40 & NT & NT & NT & NT & NT \\
\hline C. platypterum & 52 & 27.279 & 36.293 & $>47.600$ & $>1.7$ & $>1.3$ \\
\hline C. racemosum & 64 & 24.578 & 26.674 & $>47.600$ & $>1.9$ & $>1.8$ \\
\hline
\end{tabular}

NT - not tested; SI - selectivity index; D6 - chloroquine-sensitive strains of Plasmodium falciparum, W2 chloroquine-resistant strains of Plasmodium falciparum; Vero - African green monkey kidney cell line 
Table 2.

In vitro antitrypanosomal and antileishmanial activities of methanol extract of three Combretum species against $L$. donovani and T. brucei brucei

\begin{tabular}{|c|c|c|c|c|c|c|c|c|c|c|c|}
\hline \multirow[t]{3}{*}{ S/No } & \multirow[t]{3}{*}{ Plant extract } & \multicolumn{5}{|c|}{ Primary assay [percentage inhibition, \%] } & \multicolumn{5}{|c|}{ Secondary Assay $\left[\mathrm{IC}_{50}, \mu \mathrm{g} / \mathrm{ml}\right]$} \\
\hline & & \multicolumn{3}{|c|}{ L. donovani } & \multirow{2}{*}{$\begin{array}{c}T . \\
\text { brucei }\end{array}$} & \multirow{2}{*}{ THP1 } & \multicolumn{3}{|c|}{ L. donovani } & \multirow{2}{*}{ T. brucei } & \multirow{2}{*}{ THP1 } \\
\hline & & $\mathrm{P}$ & A & AT & & & $\mathrm{P}$ & A & AT & & \\
\hline 1. & C. zenkeri & 0 & 23 & 1 & 14 & 11 & $>20$ & $>20$ & $>20$ & $>20$ & $>20$ \\
\hline 2. & C. platypterum & 0 & 27 & 0 & 16 & 11 & $>20$ & $>20$ & $>20$ & $>20$ & $>20$ \\
\hline 3. & C. racemosum & 0 & 3 & 0 & 54 & 0 & $>20$ & $>20$ & $>20$ & 18.44 & $>20$ \\
\hline
\end{tabular}

THP-1 - transformed human monocyte cell line; P - promastigote; A - amastigote; AT - amastigote/THP

percentage inhibition of $11 \%$ (tab. 2). However, C. platypterum and C. racemosum showed moderate cytotoxicity on Vero cells with $\mathrm{IC}_{50}$ values $>47 \mu \mathrm{g} / \mathrm{ml}$.

\section{DISCUSSION}

Natural products obtained from medicinal plants have been utilised for many years by diverse communities for the management of many diseases. Historically, the earliest written report of the use of natural products in health care are from Mesopotamia (2600 B.C.), which recorded several plant-derived substances on tablets of clay, including the oils of $\mathrm{Cu}$ pressus sempervirens L. (Cupressaceae), Glycyrrhiza glabra L. (Leguminosae) and Papaver somniferum L. (Papaveraceae) [25]. Natural medicinal agents have contributed immensely to drug discovery as nearly three quarter of medicines used in today's drug industry are models of natural products [26]. Many Combretum species are used in traditional African medicines for the treatment of several conditions including worm infections, abdominal pain, Hansen's disease and trypanosomiasis [19]. In view of this, three Combretum species indigenous to Nigeria were investigated for their in vitro antiprotozoal activity against Plasmodium falciparum, Trypanosoma brucei brucei and Leishmania donovani.

Among the plant extracts examined in this study, C. racemosum extract showed the most significant antiplasmodial activity with $\mathrm{IC}_{50}$ values of $25.6 \mu \mathrm{g} / \mathrm{ml}$ and $26.7 \mu \mathrm{g} / \mathrm{ml}$, respectively, against P. falciparum strains D6 and W2. The extract of C. platypterum displayed slighter lower antiplasmodial activity, when compared to C. racemosum, with $\mathrm{IC}_{50}$ values of $27.3 \mu \mathrm{g} / \mathrm{ml}$ and $36.3 \mu \mathrm{g} / \mathrm{ml}$, respectively, against D6 and W2 strains of $P$. falciparum. In this study, the antiplasmodial activity shown by
C. racemosum and C. platypterum extracts is in line with a recent study where the extracts demonstrated higher antiplasmodial activity than chloroquine using the $\beta$-hematin inhibition assay [27]. It is noteworthy that C. zenkeri had no significant activity using $\mathrm{pLDH}$ assay in this work, however, in previous study it had moderate $\beta$-hematin inhibitory activity [27]. Another earlier study reported the antiplasmodial activity of C. racemosum leaf extract against chloroquine-resistant and pyrimethamine-resistant strains of $P$. falciparum which was determined using a modified $[3 \mathrm{H}]$-hypoxanthine incorporation assay [28]. In addition, C. platypterum methanol extract displayed a better selectivity towards the chloroquine-sensitive $P$. falciparum strain ( $\mathrm{SI}=>1.7$ ), as compared to the chloroquine-resistant $P$. falciparum strain $(\mathrm{SI}=>1.3)$. A similar observation was noted for the methanol extract of C. racemosum. Although C. racemosum and C. platypterum displayed significant antiplasmodial activity in this work, their low selectivity indices $(\mathrm{SI}<2)$ may be an indication of a narrow safety margin in therapeutic use. To the best of our knowledge, this is the first report on the antiplasmodial activity of C. platypterum.

The antitrypanosomal potential displayed by C. racemosum in this work $\left(\mathrm{IC}_{50}\right.$ value $\left.=18.44 \mu \mathrm{g} / \mathrm{ml}\right)$ stays in agreement with previous findings of Eze et al. [29] where the leaf extract of C. racemosum immobilised T. brucei brucei and reduced parasitaemia in infected mice. Similarly, an earlier study reported the antitrypanosomal activity of $C$. racemosum leaf extract against $T$. brucei rhodesiense with $\mathrm{IC}_{50}$ value of $24 \mu \mathrm{g} / \mathrm{ml}$ [28]. It is notable that although C. racemosum was active against T. brucei brucei, it lacked significant activity on the promastigote and amastigote forms of L. donovani.

C. racemosum, commonly called 'ogan pupa' by the Yoruba ethnic group of southwestern Nigeria, 
is a shrub used in Nigerian traditional medicine for the treatment of anaemia, cholera, diabetes, haemorrhoids, ulcer, trypanosomiasis, worm infections, haematuria, convulsion, cough, toothache, male sterility and tuberculosis $[29,30]$. The phytochemical constituents of C. racemosum leaf extract includes alkaloids, steroids, cardiac glycosides, saponins and tannins [31]. Various pharmacological studies have validated the ethnomedicinal use of the plant in the management of several ailments including cancer, ulcer, inflammation, microbial infections, spasms, trypanosomiasis and termination of unwanted pregnancy [29, 32-37]. In a recent study, several pentacyclic triterpenoids including combregenin, combreglucoside, arjungenin, arjunolic acid, chebuloside II and bellericaside B were isolated from the roots of $C$. racemosum [37]. In the same study, 3-O- $\beta$-acetyl-ursolic acid, betulinic acid, and quadranoside II displayed significant cytotoxic activity against some carcinoma cell lines with $\mathrm{IC}_{50}$ values, while arjungenin, terminolic acid and 3-O- $\beta$-acetyl-ursolic acid showed moderate antimicrobial activity against some Gram-positive bacteria [37].

\section{CONCLUSION}

The present study demonstrates that the methanol extract of Combretum racemosum leaves possesses remarkable antiplasmodial and antitrypanosomal activities but lacks in significant antileishmanial properties. In addition, the antiplasmodial potential of the methanol extract of the leaves of Combretum platypterum is reported for the first time. However, it was observed that the extract of Combretum zenkeri lacked significantly in the activity against Plasmodium falciparum, Leishmania donovani and Trypanosoma brucei brucei. The phytochemical variations that exist among species of the same genus could account for this variation in the antiprotozoal activities of these three Combretum species. This work may provide supporting evidence for the ethnomedicinal use of $C$. racemosum leaves in the treatment of malaria and parasitic infections in African traditional medicine. Therefore, further analysis of this plant is needed in order to identify the molecules that could be responsible for the antiplasmodial and antitrypanosomal activity, as this could provide lead compounds for drug discovery and development to combat these tropical diseases.

\section{ABBREVIATIONS}

D6 - chloroquine-sensitive strains of Plasmodium falciparum

DMSO - dimethylsulfoxide

FHI - Forest Herbarium Ibadan

FRIN - Forestry Research Institute of Nigeria

HAT - human African trypanosomiasis

NTDs - neglected tropical diseases

PLDH - plasmodium lactate dehydrogenase

RPMI - Roswell Park Memorial Institute

SI - selectivity index

THP-1 - transformed human monocyte cell line

Vero - African green monkey kidney cell line

W2 - chloroquine-resistant strains of Plasmodium falciparum

WHO- World Health Organization

\section{ACKNOWLEDGEMENTS}

We acknowledge the National Centre for Natural Products Research, School of Pharmacy, University of Mississippi, USA, for providing facilities and materials for the in vitro antiprotozoal assays.

Conflict of interest: Authors declare no conflict of interest.

\section{REFERENCES}

1. Mahady GB. Medicinal plants for the prevention and treatment of bacterial infections. Curr Pharm Des 2005; 11:2405-2427. doi: http:// dx.doi.org/10.2174/1381612054367481

2. Mtunzi FM, Ejidike IP, Ledwaba I, Ahmed A, Pakade VE, Klink MJ, et al. Solvent-solvent fractionations of Combretum erythrophyllum (Burch.) leave extract: Studies of their antibacterial, antifungal, antioxidant and cytotoxicity potentials. Asian Pac J Trop Med 2017; 10:670-679. doi: http://dx.doi.org/10.1016/j.apjtm.2017.07.007

3. WHO. Working to overcome the global impact of neglected tropical diseases: first WHO report on neglected tropical diseases 2010.

4. Llurba-Montesino N, Kaiser M, Brun R, Schmidt TJ. Search for antiprotozoal activity in herbal medicinal preparations; new natural leads against neglected tropical diseases. Molecules 2015; 20:14118-14138. doi: http://dx.doi.org/10.3390/ molecules 200814118 
5. Hotez PJ, Alvarado M, Basáñez MG, Bolliger I, Bourne R, Boussinesq $M, t$ al Buckle G, Budke CM. The global burden of disease study 2010: interpretation and implications for the neglected tropical diseases. PLoS Neg Trop Dis 2014; 8:e2865. doi: http://dx.doi.org/10.1371/journal. pntd.0002865

6. Shuford KV, Turner HC, Anderson RM. Compliance with anthelmintic treatment in the neglected tropical diseases control programmes: a systematic review. Parasites \& Vectors 2016; 9:29. doi: http://dx.doi.org/10.1186/s13071-016-1311-1

7. Molyneux DH, Savioli L, Engels D. Neglected tropical diseases: progress towards addressing the chronic pandemic. The Lancet 2017; 389:312-325. doi: http://dx.doi.org/10.1016/S0140-6736(16)30171-4

8. Mehani M, Segni L, Terzi V, Morcia C, Ghizzoni R, Goudgil B, et al Antifungal activity of Artemisia herba-alba on various Fusarium. Phytothérapie 2016; 1-4. doi: http://dx.doi.org/10.1007/s10298016-1071-2

9. Al-Judaibi E. Infection and antibiotic resistant bacteria in developing countries: A genetic review. J Microbiol Res 2014; 4:10-17. doi: http:// dx.doi.org/10.5923/s.microbiology.201401.02

10. Paladini A, Fusco M, Cenacchi T, Schievano C, Piroli A. Palmitoylethanolamide, a special food for medical purposes, in the treatment of chronic pain: a pooled data metaanalysis. Pain Physician 2016; 19:11-24.

11. Segun PA, Ogbole OO, Ajaiyeoba EO. Medicinal plants used in the management of cancer among the Ijebus of southwestern Nigeria. J Herb Med 2018; 14:68-75. doi: http://dx.doi.org/10.1016/j. hermed.2018.04.002

12. Frausin G., Lima RBS, Hidalgo A, Ming LC, Pohlit AM. Plants of the Araceae family for malaria and related diseases: a review. Rev Bras Plantas Med 2015; 17:657-666. doi: http://dx.doi. org/10.1590/1983-084X/14_024

13. Roy S, Gorai D, Acharya R, Roy R. Combretum (Combretaceae): Biological activity and phytochemistry. Indo American J Pharm Res 2014; 4:5266-5299. doi: http://dx.doi.org/10.1044/1980iajpr.141107
14. Hutchings A. Zulu medicinal plants: An inventory, edn. University of Natal Press, 1996. doi: http://dx.doi.org/10.1021/np970084y

15. Masoko P, Picard J, Eloff J. The antifungal activity of twenty-four southern African Combretum species (Combretaceae). S Afr J Bot 2007; 73:173-183. doi: http://dx.doi.org/10.1016/j.sajb.2006.09.010

16. Ogbole OO, Ayeni FA, Ajaiyeoba EO. In-vitro antibacterial screening of methanol extracts of three Combretum species against seven strains of methicillin resistant Staphylococcus aureus (MRSA). Nig J Pharm Res 2016; 12:149-154.

17. Santos SN, Ferraris FK, de Souza AO, das Graças Henriques M, Melo IS. Endophytic fungi from Combretum leprosum with potential anticancer and antifungal activity. Symbiosis 2012; 58:109117. doi: http://dx.doi.org/10.1007/s13199-012$0218-7$

18. McGaw L, Rabe T, Sparg S, Jäger A, Eloff J, Van Staden J. An investigation on the biological activity of Combretum species. J Ethnopharmacol 2001; 75:45-50. doi: http://dx.doi.org/10.1016/ S0378-8741(00)00405-0

19. Eloff J, Katerere D, McGaw L. The biological activity and chemistry of the southern African Combretaceae. J Ethnopharmacol 2008; 119:686-699. doi: http://dx.doi.org/10.1016/j.jep.2008.07.051

20. Samoylenko V, Jacob MR, Khan SI, Zhao J, Tekwani BL, Midiwo JO, et al. Antimicrobial, antiparasitic and cytotoxic spermine alkaloids from Albizia schimperiana. Nat Prod Comm 2009; 4:791. doi: http://dx.doi.org/10.7763/IPCBEE.2012.V49.30

21. Bello O, Zaki A, Khan S, Fasinu P, Ali Z, Khan I, et al. Assessment of selected medicinal plants indigenous to West Africa for antiprotozoal activity. S Afr J Bot 2017; 113:200-211. doi: http://dx.doi. org/10.1016/j.sajb.2017.08.002

22. Mikus J, Steverding D. A simple colorimetric method to screen drug cytotoxicity against Leishmania using the dye Alamar Blue ${ }^{\oplus}$. Parasitology Int 2000; 48:265-269. doi: http://dx.doi. org/10.1016/S1383-5769(99)00020-3

23. Jain S, Jacob M, Walker L, Tekwani B. Screening North American plant extracts in vitro against Trypanosoma brucei for discovery of new anti- 
trypanosomal drug leads. BMC Comp Alt Med 2016; 16:131. doi: http://dx.doi.org/10.1186/ s12906-016-1122-0

24. Jain SK, Sahu R, Walker LA, Tekwani BL. A parasite rescue and transformation assay for antileishmanial screening against intracellular Leishmania donovani amastigotes in THP1 human acute monocytic leukemia cell line. J Visualized Exp 2012; 70:4054. doi: http://dx.doi. org/10.3791/4054

25. Harvey AL. Natural products in drug discovery. Drug Disc Today 2008; 13:894-901. doi: http:// dx.doi.org/10.1016/j.drudis.2008.07.004

26. Newman DJ, Cragg GM. Natural products as sources of new drugs from 1981 to 2014 . J Nat Prod 2016; 79:629-661. doi: http://dx.doi. org/10.1021/acs.jnatprod.5b01055

27. Wande OM, Babatunde SB. In vitro screening of ten Combretaceae plants for antimalarial activities applying the inhibition of beta-hematin formation. Int J Biol Chem Sci 2017, 11:2971-2981. doi: http://dx.doi.org/10.4314/ijbcs.v11i6.33

28. Atindehou K, Schmid C, Brun R, Koné MW, Traore D. Antitrypanosomal and antiplasmodial activity of medicinal plants from Côte d'Ivoire. J Ethnopharmocol 2004; 90:222-227. doi: http:// dx.doi.org/10.1016/j.jep.2003.09.032

29. Eze JI, Anosa GN, Ozota CA. In vitro and in vivo trypanocidal activity of Combretum racemosum leaves. Afr J Biotec 2012; 11:10611-10616. doi: http://dx.doi.org/10.5897/AJB11.1014

30. Okwuasa C, Nwobode E, Chilaka K. The anti-ulcer activities of leaf extracts of Combretum racemosum (family: Combracaceae). J Biomedical Inv 2006; 4:9-14. doi: http://dx.doi.org/10.4314/jbi. v4i1.30408
31. Onocha P, Audu E, Ekundayo O, Dosumu O. Phytochemical and antimicrobial properties of extracts of Combretum racemosum. Acta Hort 2005;675:97-101.doi:http://dx.doi.org/10.17660/ ActaHortic.2005.675.12

32. Akubue PI, Mittal GC, Aguwa CN. Preliminary pharmacological study of some Nigerian medicinal plants. J Ethnopharmocol 1983; 8: 53-63. doi: http://dx.doi.org/10.1016/0378-8741(83)90089-2

33. Manga FN, Khattabi CE, Fontaine J, Berkenboom G, Duez P, Nzunzu JL, et al. Vascular effects and antioxidant activity of two Combretum species from Democratic Republic of Congo. J Ethnopharmocol 2012; 4:194-200. doi: http://dx.doi. org/10.1016/j.jep.2012.04.039

34. Babatunde S, Moyinoluwa O, Oluwatosin A, Eigege W, Shreyans J. Bioguided isolation of an antioxidant compound from Combretum racemosum P. Beav leaf. Int J Bio Chem Sci 2014; 8:23392346. doi: http://dx.doi.org/10.4314/ijbcs.v8i5.36

35. Kola KA, Benjamin AE. Comparative antimicrobial activities of the leaves of Combretum micranthum and Combretum racemosum. Global J Med Sci 2002; 1:13-17. doi: http://dx.doi.org/10.4314/ gjms.vli1.10103

36. Schepetkin IA, Kouakou K, Yapi A, Kirpotina LN, Jutila MA, Quinn MT. Immunomodulatory and hemagglutinating activities of acidic polysaccharides isolated from Combretum racemosum. Int Immunopharmacol 2013; 15:628-637. doi: http://dx.doi.org/10.1016/j.intimp.2013.01.015

37. Gossan DPA, Magid AA, Yao-Kouassi PA, Josse J, Gangloff SC, Morjani H, et al. Antibacterial and cytotoxic triterpenoids from the roots of Combretum racemosum. Fitoterapia 2016; 110:89-95. doi: http://dx.doi.org/10.1016/j.fitote.2016.03.002 